\title{
A Study of Teacher Efficacy of Special Education Teachers of English Language Learners with Disabilities
}

\author{
Oneyda M. Paneque \\ Barry University, USA \\ Patricia M. Barbetta \\ Florida International University, USA
}

\begin{abstract}
This research examined the perceived teacher efficacy of special education teachers of English Language Learners with disabilities. The results demonstrate the positive correlation between proficiency in the language of the target students and teacher efficacy. An analysis of responses yielded two major themes, organizational and teacher issues, affecting teacher performance.
\end{abstract}

Teacher efficacy is the teacher's belief in his or her capability to organize and execute courses of action to successfully accomplish specific instructional tasks or, more simply, his or her capacity to affect student performance (Bandura, 1995). Teachers with a high sense of efficacy have a strong conviction that they can influence student learning, even the learning of those students who may be more challenging (Guskey \& Passaro, 1994). These teachers are open to new ideas and are more willing to experiment with and try new teaching strategies to better meet their students’ needs (Ghaith \& Yaghi, 1997; Guskey, 1988). Overall, efficacious teachers tend to engage in more productive, quality teacher behaviors (Ashton \& Webb, 1986; Gibson \& Dembo, 1984). In contrast, teachers with low efficacy feel they only have minimal influence on student achievement. These teachers give up more easily when confronted with a difficult situation, are less resourceful, and oftentimes feel that students cannot learn because of the extenuating circumstances (Ashton \& Webb, 1986; Bandura, 1997). Due to the selection of more effective and positive teaching behaviors, efficacious teachers tend to have high student achievement, whereas teachers with low efficacy tend to have low student achievement.

The purpose of this study was to examine the efficacy beliefs of special education teachers working with English Language Learners (ELLs) with disabilities who are at risk of academic failure. Contributing to their at risk status are their cognitive, emotional and/or physical disabilities and their limited proficiency in English. In addition, many of these students come from low socioeconomic families (Smith, 2001) adding another dimension of risk of academic failure. Baca and Cervantes (2004) refer to students who have a disability, a nonEnglish language background, and low socioeconomic status, as having "three strikes against them" (p. 2). The presence of all three risk factors exponentially increases the probability of failure. Therefore, the theory of teacher efficacy is particularly relevant because of the special needs of ELLs with disabilities and the demands placed on their teachers to help these students achieve academic success.

\section{Theoretical Framework}

The construct of teacher efficacy has evolved from Bandura's $(1977,1997)$ work in the general area of self-efficacy. The theory posits that the perceptions of one's ability affect one's thoughts, feelings, motivation, and actions. Bandura (1995) identified four primary sources of efficacy development: mastery experiences, vicarious experiences, physiological and emotional states, and social persuasion. Of these four sources of efficacy development, mastery experiences 
are the most influential (Bandura, 1997). Bandura (1997) suggested that once efficacy beliefs are formed, they are very difficult to change. Therefore, it is easier to affect change when teachers are in formative process in teacher preparation programs rather than when they are in the classroom. This is particularly important because of the implications for both preprofessional teacher education programs and teacher development programs.

Studies examining teacher efficacy in the field of special education have found that teachers with higher efficacy make fewer referrals to special education (Meijer \& Foster, 1988; Podell \& Soodak, 1993; Soodak \& Podell, 1993), feel more responsible for student learning (Soodak \& Podell, 1994), report more success with students with learning and behavioral problems (Brownell \& Pajares, 1996, 1999), and are more receptive to inclusion of students with disabilities in the mainstream classrooms (Buell, Hallam, Gamel-McCormick, \& Scheer, 1999; Freytag, 2001; Soodak, Podell, \& Lehman, 1998).

Two studies (Kwiat, 1989; Tasan, 2001) address teacher efficacy of teachers of ELLs. In both studies, differences were noted after the participants engaged in professional development activities. These studies suggest that teacher preparation and professional development affect teacher efficacy.

Despite the increasing numbers of ELLs with disabilities receiving special education services (Heubert, 2002), only one study included an examination of efficacy beliefs of special educators with respect to these students (Carlson, Brauen, Klein, Schrool, \& Willig, 2002). In that study, special educators had high perceptions of their efficacy overall. One area where they did report feeling less efficacious was in accommodating the needs of culturally and linguistically diverse students with disabilities. This finding points to the need for research in the area of teacher efficacy of special education teachers of ELLs with disabilities.

This present study examined the special education teachers' perceptions of efficacy when teaching students who are ELLs with disabilities. In addition, the study sought to obtain information about the views of the teachers regarding effective practices when working with the target students. The research questions posed were:

1. Is there a correlation between teacher variables and teacher efficacy for special education teachers of ELLs with disabilities?

2. Which of the independent teacher variables are the best predictors of perception of teacher efficacy for special education teacher working with ELLs with disabilities?

3. What are special education teachers' views on what is most helpful for themselves, as well as preservice and inservice teachers, when working with ELLs with disabilities?

Teacher variables examined included: highest degree earned, degree in an area of special education, certification in special education, teaching experience, status of English for Speakers of Other Languages (ESOL) endorsement, proficiency in the language of the students, and Title I status of the school as an indicator of the socioeconomic level of the school population. Data on participants' views added to the understanding of teacher efficacy for this population.

\section{Method}

A survey approach was implemented utilizing an instrument specifically designed for the study in accordance with Bandura's (2001) Guide for Constructing Self-efficacy Scales. The Exceptional Children who are English Learners (EXCEL) Teacher Inventory was comprised of three sections. The 20 items in Section I measured teacher efficacy in working with ELLs with disabilities. Participants were asked to rate themselves using a 9-point Likert scale on their perceptions of their abilities in areas of specific teacher competencies that affect student performance. Teacher competencies were identified following the guidelines established by the 
national organizations in the areas of TESOL/bilingual education (National Association for Bilingual Education, 1992; TESOL, 2001) and special education (Council for Exceptional Children, 2003). Section II had three open-ended questions related to what participants thought had helped preservice and inservice teachers as well as themselves the most in working with the target students. Section III had items on teacher demographic variables including types of preparation, experience, and proficiency in the language of the ELLs.

Since the EXCEL Teacher Inventory was developed specifically for the study, reliability and validity were established. The coefficient alpha was calculated at .9419 indicating highly satisfactory internal reliability. Content validity was established by creating a table of specification using the teacher competency areas identified through the review of the literature. Furthermore, face validity was established by a review panel of three experts, Dr. Leonard Baca, BUENO Center for Multicultural Education, University of Colorado; Ms. Rosalia Gallo, MiamiDade County Public Schools, Bilingual/ESOL ESE Programs; and Dr. Diane Rodriguez, ESE/TESOL Programs, Barry University, and a group of 20 special education teachers. Their recommendations assisted in making revisions and corrections which contributed to the clarity and appropriateness of the instrument. Two hundred two teachers at 31 elementary school sites located in a large urban school district participated in the study. The return rate was 58.5\%.

Correlations and $t$-tests were calculated between total teacher efficacy scores and each of the teacher demographic variables. Descriptive statistics, including frequency distributions and measures of central tendency, provided a description of the participants and the pattern of their responses to the total teacher efficacy score. In addition, a multiple regression was used to analyze which of the teacher variables were the best predictors of teacher efficacy. The predictor variables were Title I status of school, highest degree earned, teaching certification, teaching experience, status of ESOL endorsement, and proficiency in languages other than English.

Responses to the open-ended questions regarding special education teachers' preparation and professional development, experiences, and recommendations for teacher preparation were coded and analyzed for response patterns following qualitative data analysis procedures (Bogdan \& Biklen, 1998; Glesne, 1999). Initially, a list of the responses for each question was compiled; these were coded and categorized according to common words, phrases, and ideas for each question as well as across the set of responses for the three questions.

\section{Results}

The analysis of the demographic data on the participants revealed that the majority of the participants (72.8\%) worked at Title I schools, held degrees in special education (84.7\%), held graduate degrees ((60.2\%), were certified in an area of special education ((92.1\%), and were ESOL endorsed (70.3\%). In addition, most of the participants (66.3\%) reported to be proficient in the language of the target students. The language most frequently reported by the participants was Spanish; the majority of the participants had less than 7.5 years of teaching experience.

Overall, participant teacher efficacy scores were high. For the 20 individual teacher efficacy items, most of the individual scores ranged from 3 to 9 on the 9-point Likert scale. The mean scores for these items ranged from 6.44 to 8.16. Correlations between teacher variables and teacher efficacy scores revealed that proficiency in the language of the target students was the statistically significant variable $(p=.002)$. No statistically significant differences in teacher efficacy scores were found for (a) variables related to teacher preparation, (b) number of years of teaching experience, or (c) Title I status of the schools where the teachers worked. The multiple regression equation found that proficiency in the language of the target students was statistically significant in predicting teacher efficacy $(p=.001)$. 
Qualitative analysis of the responses to the opened questions yielded two major thematic categories: organizational issues and teacher issues affecting teacher performance. The majority of the responses to the open-ended questions were regarding teacher issues. Organizational issues included responses in the areas of support from others, availability of resources, class size, time constraints, and funding. Support from others and availability of resources were most frequently reported by participants for themselves, inservice teachers, and preservice teachers. Teacher issues included teacher disposition, teacher preparation, teaching experience, teaching skills, and language skills. Responses about teacher preparation were most frequently reported for the participants themselves, as well as for preservice and inservice teachers. For preservice teachers, field based learning experiences were frequently recommended and for inservice teachers professional development activities were recommended. Differences in responses were noted among participants who reported to be proficient in the language of the target students and those who reported that they were not proficient. Language proficient participants reported that fluency in the language of the target students was most helpful when working these students, although it was not recommended for preservice and inservice teachers.

\section{Conclusion}

The teacher variable that was the predictor of teacher efficacy and the one that was statistically significantly correlated to teacher efficacy was proficiency in the language of the target students. The responses to the open-ended questions revealed participants' perceptions of organizational and teacher issues that affect teaching ELLs with disabilities.

The results of the present study have implications for the practice of special education teachers working with ELLs with disabilities. The most noteworthy result regarding the language proficiency of the special education teachers suggests that teachers of the target students should have skills in the languages of their students or support from others who are language proficient. Special education teacher education programs should consider expanding their programs to include bilingual special education since there are fewer than 15 such programs in the United States (National Clearinghouse for Professions in Special Education, 2000).

Implications for preservice teacher education programs include the development of skills in languages other than English, as well as a firm understanding of the target students' language and culture to evaluate and teach successfully. Preservice teachers should also develop skills necessary to establish communication between parents and others in the learning community. In particular, instruction on strategies for working effectively with parents who speak a language other English should be incorporated into teacher education programs. Opportunities for fieldbased experiences are suggested with university professors and supervising teachers in the field who can assist in maximizing the field-based learning experiences for the preservice teachers.

For inservice teachers, implications of the results suggest that special education teachers would benefit from an infrastructure that promotes support from others and collaboration with other professionals. Suggestions from the participants for inservice training include professional development activities in the areas of cultural diversity, testing and evaluation, language development and second language acquisition, and family involvement.

In the field of teacher efficacy, limited studies have focused on special populations, i.e., students with disabilities as well as those who speak English as a second language. Further research in this area is recommended since research in the area of teacher efficacy has consistently yielded a strong relationship to student outcomes (Armor et al., 1976; Ashton \& Webb, 1986; Berman, McLaughlin, Bass, Pauly, \& Zellman, 1977; Gibson \& Dembo, 1984; Tschannen-Moran \& Hoy, 2001). Teacher efficacy affects teachers' thoughts, their actions in the 
teaching process, the effort they put forth, and their perseverance in improving student achievement (Bandura, 1997). For this reason, it is important to study the efficacy of teacher, particularly those who work with challenging students who are most in need of the best teachers. This study has contributed to the body of literature on teacher efficacy which was scarce with regard to teachers of students with disabilities as well as students from non English language backgrounds.

\section{References}

Armor, D., Conry-Oseguera, P., Cox, M., King, N., McDonnell, L., Pascal, A., et al. (1976). Analysis of the school preferred reading program in selected Los Angeles minority schools. (Report NO. R-2007-LAUSD). Santa Monica, CA: The Rand Corporation. (ERIC Document Reproduction Service No. ED 130243)

Ashton, P. T., \& Webb, R. B. (1986). Making a difference: Teachers' sense of efficacy and student achievement. White Plains, NY: Longman.

Baca, L. M., \& Cervantes, H. T. (2004). The bilingual special education interface (4 ${ }^{\text {th }}$ ed.). Upper Saddle River, NJ: Prentice-Hall.

Bandura, A. (1977). Self-efficacy: Toward a unifying theory of behavioral change. Psychological Review, 84, 191-215.

Bandura, A. (1995). Exercise of personal and collective efficacy in changing societies. In A. Bandura (Ed.), Self-efficacy in changing societies (pp. 1-45). New York: Cambridge University Press.

Bandura, A. (1997). Self-efficacy: The exercise of control. New York: W. H. Freeman.

Bandura, A. (2001). Guide for constructing self-efficacy scales (Revised). Available upon request from Frank Pajares, Emory University.

Berman, P., McLaughlin, M., Bass, G., Pauly, E., \& Zellman, G. (1977). Federal programs supporting educational change. Vol. 7: Factors affecting implementation and continuation. Santa Monica, CA: The Rand Corporation. (ERIC Document Reproduction Service No. ED 140432)

Bogdan, R. C., \& Biklen, S. K. (1998). Qualitative research in education: An introduction to theory and method. Boston: Allyn and Bacon.

Brownell, M. T., \& Pajares, F. M. (1996). The influence of teachers' efficacy beliefs on perceived success in mainstreaming students with learning and behavior problems: A path analysis. Florida Educational Research Council Research Bulletin, 27(3-4), 11-24. (ERIC Document Reproduction Service No. ED 409661)

Brownell, M. T., \& Pajares, F. M. (1999). Teacher efficacy and perceived success in mainstreaming students with learning and behavior problems. Teacher Education and Special Education, 22(3), 154-164.

Buell, M. J., Hallam, R., Gamel-McCormick, M., \& Scheer, S. (1999). A survey of general and special education teachers' perceptions and inservice needs concerning inclusion. International Journal of Disability, Development and Education, 46(2), 143-156.

Carlson, E., Brauen, M., Klein, S., Schroll, K., \& Willig, S. (2002). Study of personnel need in special education. Rockville, MD: Westat Research Corporation. Retrieved February 20, 2004, from http://www.ecs.org/html/offsite.asp?document=http\%3A\%2F\%2Fwww\%2 Espense\%2Eorg\%2F+

Council for Exceptional Children. (2003). What every special educator must know: Ethics, standards, and guidelines for special educators ( $5^{\text {th }}$ ed.). Reston, VA: Author. 
Freytag, C. E. (2001, February). Teacher efficacy and inclusion: The impact of preservice experiences on beliefs. Paper presented at the annual meeting of the Southwest Educational Research Association, New Orleans, LA. (ERIC Document Reproduction Service No. ED 451180)

Ghaith, G., \& Yaghi, H. (1997). Relationships among experience, teacher efficacy, and attitudes toward the implementation of instructional innovation. Teaching and Teacher Education, 13(4), 451-458.

Gibson, S., \& Dembo, M. (1984). Teacher efficacy: A construct validation. Journal of Educational Psychology, 76, 569-582.

Glesne, C. (1999). Becoming qualitative researchers: An introduction. New York: Longman.

Guskey, T. R. (1988). Teacher efficacy, self-concept, and attitudes toward the implementation of instructional innovation. Teaching and Teacher Education, 4, 63-69.

Guskey, T. R., \& Passaro, P. D. (1994). Teacher efficacy: A study of construct dimensions. American Educational Research Journal, 31, 627-643.

Heubert, J. P. (2002). Disability, race, and high-stakes testing of students. In D. J. Losen \& G. Orfield (Eds.), Racial inequity in special education (pp.137-165). Cambridge, MA: Harvard Education Press.

Kwiat, J. (1989, March). Perspectives on fostering change in teachers of language minority students. Paper presented at the annual meeting of the American Educational Research Association, San Francisco, CA. (ERIC Document Reproduction Service No. ED306767)

Meijer, C., \& Foster, S. (1988). The effect of teacher self-efficacy on referral chance. Journal of Special Education, 22, 378-385.

National Association for Bilingual Education. (1992). Professional standards for the preparation of bilingual/multicultural teachers. Washington, DC: Author. (ERIC Document Reproduction Service No. ED 355825)

National Clearinghouse for Professions in Special Education. (2000). Personnel training programs to teacher bilingual special education. Reston, VA: Author.

Podell, D. M., \& Soodak, L. C. (1993). Teacher efficacy and bias in special education referrals. Journal of Educational Research, 86, 247-253.

Smith, D. D. (2001). Introduction to special education: Teaching in an age of opportunity. Boston: Allyn and Bacon.

Soodak, L. C., \& Podell, D. M. (1993). Teacher efficacy and student problem as factors in special education referral. The Journal of Special Education, 27, 66-81.

Soodak, L. C., \& Podell, D. M. (1994). Teachers' thinking about difficult-to-teach students. Journal of Educational Research, 88(1), 44-51.

Soodak, L. C., Podell, D. M., \& Lehman, L. R. (1998). Teacher, student, and school attributes as predictors of teachers' responses to inclusion. The Journal of Special Education, 31, 480497.

Tasan, A. P. (2001, April). Teacher efficacy and diversity: Implications for teacher training. Paper presented at the annual meeting of the American Educational Research Association, Seattle, WA. (ERIC Document Reproduction Service No. ED 453201)

Teachers of English to Speakers of Other Languages. (2001). TESOL P-12 ESL Teacher Standards. Washington, DC: Author.

Tschannen-Moran, M., \& Hoy, A. (2001). Teacher efficacy: Capturing an elusive construct [Electronic version]. Teaching and Teacher Education, 17, 783-805. 